\title{
Preferences, Power, and the Determination of Working Hours
}

\author{
Bruce Philp, \\ Gary Slater, \\ and \\ David Harvie
}

To develop a meaningful understanding of living standards and the distribution of income in capitalist economies, it is important to consider the length of the working day. Since Karl Marx's discussion, in part 4 of Capital's first volume, of relative surplus value, there have been debates over the intensive utilization of labor. More recently, these debates have extended to considering the application of neoclassical rational-choice methodology in explanations of labor extraction. ${ }^{1}$ However, there have been historical periods during which the extensive utilization of labor has predominated, manifest in the form of increases in the length of the working day and/or reductions in holidays (see Hobsbawm 1968; Bienefeld 1972). There have also been periods when working hours have fallen, and the trend for nearly all advanced capitalist economies, including Britain, for most of the twentieth century was downward. In the 1980s, however, the downward trend in average hours in Britain and the United States halted, and simultaneously work effort began to be intensified (Green 2001; Schor 1991). It is important to explain why and how working hours increase, decrease, or remain constant in particular periods of history, and this paper intends to explore a number of perspectives on the determination of working hours. It is further suggested that Marxism and institutionalism may both contribute to our understanding and indeed have elements in common.

Economists working within neoclassical economics, and a number of heterodox traditions, have offered alternative theories identifying the determinants of working hours. Neoclassical approaches have tended to emphasize individual choice subject to budget constraints. Institutionalist economists have frequently rejected such forms of

The authors are Lecturers in the Department of Accounting, Finance, and Economics at Nottingham Trent University, U.K. They would like to thank Glen Atkinson and two anonymous referees for helpful comments on an earlier draft. The usual disclaimer applies. 
analysis, suggesting this emphasis on maximizing behavior is misplaced. Instead, they argue, there emerge norms or ideals, which are in part determined by the institutional structure (one example might be the establishment of a normal working day). Finally, Marxian approaches explain the determination of working hours as an outcome of a class struggle between collective capital and collective labor (one such explanation is offered by Philp 2001). In such approaches, it is power and conflict, rather than individual rational choice in a harmonious environment, that are key in explaining the duration and dynamics of working hours.

Recent interest in the hours people work has been stimulated by a number of factors. First, the high and persistent levels of unemployment exhibited in many European Union economies has prompted interest in policies which redistribute work from the employed to the unemployed. Recent work by Gerhard Bosch and Steffen Lehndorff (2001) evaluates the use of working-hour reductions as an employment policy, suggesting that this is potentially an effective instrument. John Maynard Keynes also identified three elements in maintaining full employment, namely, a sound investment policy, increased consumption, and reductions in average working hours. He suggested "[h]ow you mix up the three ingredients of a cure is a matter of taste and experience, i.e. of morals and knowledge" $(1980,384)$. In spite of this recognition, however, Keynes was skeptical of short-time working at the industry level since this entailed idle machinery for long periods of the working week (see Cameron and Ndlovu 1999). Thus Keynes maintained, "The cotton industry ... has ruined itself by organized short-time extending over five years, which, by increasing overhead expenses, has raised its costs of production above the competitive level" $(1981,578)$. As a short-term policy Keynes was thus critical of short time, but in the long run he suggested reduced working hours could be one way to maintain full employment. In fact, recent proposals to limit working time in countries such as Germany have addressed this issue by seeking to tie working-time reductions to increased flexibility on the part of workers. It is this factor which has provoked left criticism, which has noted that what is being posited is a thirty-five-hour working week, not a seven-hour working day.

For economists not committed to fundamental redistribution of income the issue of how reductions in working hours are to be funded is problematic. Bosch and Lehndorff have suggested that working time should be reduced as part of a long-term package linking wages, conditions, and increased productivity through time: "In this way, cuts in working time and wage increases can be implemented simultaneously ... without causing a rise in real unit wage costs, which are particularly important in determining international competitiveness" $(2001,239){ }^{2}$ The effect of rising wage costs has also concerned Franco Modigliani et al., who have suggested that the claim that working hours should be reduced while maintaining the weekly wage amounts to "little more than demagogy" $(1998,339)$. They have suggested that increased labor costs could hardly be expected to come out of profits and that the outcome of reduced working hours without an equivalent reduction in weekly wages would be higher prices, reinforcing the inflationary spiral. The emphasis on avoiding inflationary pressure through lim- 
iting the increase in wage costs has also been advanced from within post-Keynesian economics. In advocating incomes policies Paul Davidson has suggested, "One of the most important functions of government in any anti-inflationary struggle is to educate the public that any ongoing income distribution struggle is ultimately costly for all" (1991, 124). In contrast Marxist economists are, of course, not committed to maintaining the prevailing distribution of income between classes and would consider working hour reduction as one element in the class-based conflict over the distribution of power, wealth, and work.

A further policy issue concerns health and safety. Indeed Morris Copeland (1931) has argued that such concerns are principal reasons behind factory legislation aimed at curbing excess working hours. Some evidence can be brought to bear to illustrate this point. Studying workers in California, P. Buell and L. Breslow (1960) found that men working more than forty-eight hours per week had double the incidence of coronary heart disease compared to those working below this total. The extensive meta-analysis conducted by K. Sparks et al. (1997) also supports the view that there is a link between long work hours and ill health. There is thus a body of evidence suggesting that some workers are suffering adverse health symptoms, such as death, connected to overwork. Such policy concerns have prompted the recent interest in the economic and social impact of longer/shorter working hours. However, it is important to reflect on what factors determine the hours of work and to consider at what level working hours are determined. This relates to the philosophical issue of microreduction, and in the following section the relevance of this will be demonstrated before considering a number of competing perspectives on the determination of working hours.

The paper is structured as follows. Initially we consider, from the perspective of the philosophy of science, the microfoundations approach, upon which the construction of the neoclassical labor-supply function is based. Since neoclassical economists emphasize acts of constrained optimization by individual agents, with given preferences, whereas Marxists emphasize the determination of working hours as an outcome of class conflict, such concerns are far from peripheral. In the next section, we consider some explanations from institutional and Marxist economics. In particular there emerge similarities in the analysis of the determinants of working hours offered by John R. Commons and Karl Marx. Before concluding we consider remaining differences between Marxist and institutionalist analyses of working hours.

\section{Microfounded Explanations of Working Hours}

The key question posed in this paper is what determines working hours. A number of alternative explanations may be offered. One microexplanation is that a given agent chooses to work particular hours because of his or her preferences for income and leisure time, respectively. Such an approach assumes preferences are determined exogenously, and this approach underpins the theory of labor supply in neoclassical 
economics. An alternative, macroexplanation, might be that the political power and economic circumstances (including technology) prevailing in the economy determines the hours people work. Marxian economics, in emphasizing class power, is one approach that adopts the macroexplanation of working hours. These alternative approaches raise philosophical questions with respect to levels of explanation. Neoclassical economists, and recently analytical Marxists, have challenged the validity of social scientific explanations that do not provide rigorous microfoundations. ${ }^{3}$ In addition, new institutionalism has utilized an approach which adopts neoclassical rational-choice methods.

Objections to the microfoundations approach can be raised from the perspective of the philosophy of science. On a practical level the microfoundations approach requires a considerable amount of detail, the analysis of which may be intractable. Microfoundations in social science usually refers to explaining the state and dynamics of social groups in terms of individual human beings. However, in the philosophy of science there are further reductive levels such as cells, molecules, atoms, and sub-atomic particles. Michael C. Howard and John E. King (1991) suggested it is always possible to reduce to yet lower levels and so explaining in terms of individual human beings itself involves some violation of the principles of microreduction.

As well as the practical problems of the microfoundations approach, Alan Garfinkel (1991) has raised philosophical objections. It is important to distinguish between ontological and explanatory reductionist claims since it is often assumed that the latter follows logically from the former. Garfinkel has challenged this view. Consider the example of a car stopped at a set of traffic lights. In terms of physics we have a steady stable distribution of mass and energy. A small change in the distribution of energy manifests itself as a change in the light from red to green. The light observed by the driver causes a reaction in the brain, in turn leading to a large mass (the car) being set in motion. Other factors, such as varying the intensity of the light, the height of the traffic light, or shade of red, will not cause the car to proceed; it is only a change in the electric current that will cause the car to proceed. Garfinkel suggested, "The fact that there is such instability means we cannot simply cite the underlying physics as the explanation for the cars' stopping or going" $(1991,543)$. Neither the color of the traffic light, the action of the car, nor the chemical state of the brain explains why the unstable parameter is the red-green boundary. This is, rather, socially determined. Garfinkel concluded, "[W]hat is necessary for a true explanation is an account of how the underlying space is partitioned into basins of irrelevant differences, separated by ridge lines of critical points" (552). A purely mechanical explanation therefore misses the point in that it fails to explain the source of instabilities, and that source is imposed on the underlying substratum; it does not emerge from it. The analogy to conflict over working hours is significant. We may model working hours for a particular agent as an outcome of a process in which they choose subject to a constraint. We may even accept that at a particular moment preferences may be taken as given on the basis that a particular mental state can 
be explained by describing the brain at that moment in time. But this explanation does not offer us an understanding of why the brain, and as a consequence the mental state of the person, is what it is at that particular moment. The process through which preferences are formed is highly significant in posing the question of what determines working hours.

A second problem with reduction concerns the status of macro- and microexplanations. Assume in an environment comprising foxes and rabbits that we ask why a particular rabbit gets eaten? One answer might be a macroexplanation; for example, the cause of the death of the rabbit was the size of the fox population. An alternative would be a microexplanation; for example, a given rabbit was eaten because it passed into the capture space of a given fox at a particular place and time. According to Garfinkel, the latter explanation provides us with a wealth of information, but it "contains much that is irrelevant to why the rabbit got eaten and does not really answer the question at all" $(1991,447)$. In this sense the macroexplanation offers the explanation we seek since the probability of a given rabbit being eaten is determined by the respective size of the fox and rabbit populations. The microexplanation, while detailed, does not offer a satisfactory answer to the question posed since, while it offers an explanation of the observed event, it does not explain why the probability of encounter is what it is at a particular point in time. This probability is the fundamental cause of the rabbit being eaten. The connection between this philosophical example and conflict over working hours is, again, instructive. Neoclassical approaches generally offer microexplanations of the determination of working hours. For example, neoclassical economists would suggest that a particular agent may choose to take a job working forty hours per week and that this choice reflects a preference for income and leisure respectively. An alternative explanation that might be offered by a Marxist or institutionalist economist might be that forty hours per week is the norm for that particular historical period, and the issue then becomes, why has the accepted normal working week become forty hours? Macroeconomic conditions and the economic structure-the unemployment rate, growth rates, per capita income, and economic development-provide part of the explanation to such a question. Furthermore, working hours are connected to distribution and, more generally, class struggle and the degree of class cohesion. As will be shown subsequently, both Marx and Commons acknowledged the role of class interests in the determination of the usual and accepted hours of work.

In contrast to classical political economy, which tended to consider labor supply in terms of population dynamics, neoclassical economics considers labor supply separately from demography. In neoclassical theory four factors might be identified in determining labor supply: labor force participation, working hours, effort, and the level of training and skill (the latter two determining the wage). In neoclassical theory the number of hours that people work is modeled as an outcome of a constrained-optimization problem, in which agents with exogenously given preferences for income and leisure select hours, given the wage rate. Preferences for such a trade-off are assumed to exhibit the properties of completeness, transitivity, reflexivity, nonsatiation, continuity, and strict 
convexity. Workers choose hours to work based on the principle of optimization whereby the marginal rate of substitution of leisure for income is equal to the slope of the budget line given by the hourly wage rate. The axioms of choice underpinning labor-leisure preference are, however, subject to doubt. Generally, problems of intransitive choice have been considered by George Loewenstein and Daniel Adler (1995), Graham Loomes and Robert Sugden (1982), and Amos Tversky, Paul Slovic, and Daniel Kahneman (1990). D. W. Grether and C. R. Plott suggested that "no optimization principles of any sort lie behind the simplest of human choices" $(1979,63) .{ }^{4}$ In her excellent The Overworked American, Juliet Schor has suggested that psychological evidence casts further doubt on rational choice approaches which assume given preferences, elaborating on the problems inherent in neoclassical approaches to working hour determination: 'Psychologists find that people tend to 'adapt' to their environments: that is their preferences adjust over time" $(1991,129)$. People may express content or make choices, but that may simply indicate hours and conditions are tractable rather than that their deeper desires have been fulfilled. Geoffrey Hodgson $(1999,101-116)$ has identified other problems with the axioms of choice which are adopted in the neoclassical approach to working hours. Hodgson has reminded us that empirical evidence undermines the nonsatiation axiom. Further, he has argued that accumulated skills and habits, rather than logical deduction or rational deliberation, are often the cause of social change. Thus a capitalist economy "is much more than individualistic atoms and their interactions" (92). Human cognition and action are institutionally and culturally embedded. Further, tacit knowledge plays a considerable part in human interaction, and much of this knowledge must remain inexplicit because "all codifiable knowledge is necessarily an emergent property of underlying and tacit rudiments" (47). In summary, the indifference curves which underpin labor-leisure preferences are themselves founded on axioms which have been shown to be problematic elsewhere in neoclassical economics. Thus the principles which underpin the derivation of the individual's labor supply function are flawed, and from that we can infer that deriving a labor market supply function from aggregating those of individual workers is itself problematic. ${ }^{5}$

\section{Institutions, Class Conflict, and Working Hours}

Institutionalists have challenged the view that the economic universe consists entirely of agents motivated by utility maximization, founded on the calculus of rational choice. ${ }^{6}$ Agents may be irrational, operating in an institutional framework that "conditions and controls behavior even as it is itself altered by it" (Miller 1978, 18). Capitalism itself, therefore, conditions and controls agents. This is manifest in Schor's account of working hours in the United States and has clear similarities to Marx's account of the history and the evolution of working hours in nineteenth century Britain, as elaborated upon in the first volume of Capital. Therefore, to suggest that these hours are what agents in some sense choose does not explain why these hours are what they are. The 
theory of rational choice, adopted in neoclassical economics, has also been subject to criticism from Morris Copeland (1931). In the context of the theory of labor supply, Copeland observed that the factory system has standardized working time and that such hours are affected by business, trade union, and government policy. Moreover, the marginalist principles on which the theory of labor supply are founded are undermined since " $[\mathrm{t}]$ he fatigue and routine of factory employment have tended to bring limitations of working time in the interests of public safety and health" (70). While it may be possible to conceive of examples where the individual exhibits choice in determining working hours, the structural constraints may be such that "choice" is considerably less significant than the evolutionary forces which determine the constraints faced by agents.

The work of Commons (1921), in which he distinguished "continuous" industries from all others, is also significant. Continuous industries are those which produce throughout a twenty-four-hour period with no break in the production process (e.g., when a production line operates during the day and night). These industries are different from others when we consider reducing working hours of employees. In continuous industries, Commons maintained, there cannot be a gradual reduction in working hours-factory owners must operate in shifts of twelve or eight hours per day. It follows logically from Commons' observation that in towns or geographical locations where a particular industry occupies a dominant role in a local labor market, there are implications for the standard account of labor supply. The possibility of discontinuities in individual labor supply functions arise, with the budget line (associated with different levels of income and leisure) appearing stepped. If individual agents in a local labor market are all facing the same budget line, the ensuing existence problems for that local labor market may be significant. In the context of continuous industries Commons recommended the introduction of legislation restricting hours of work to eight hours. However, Commons suggested profound problems of enforcement and evasion faced factory inspectors. Thus, "[a]ll jobs in the same establishment must be reduced to eight hours in order to enforce the eight-hour limit on continuous jobs" $(1921,809)$. Moreover, Commons suggested that overtime should be prohibited.

Marx noted that when legal restrictions on working hours are introduced it is often the case that a few, or many industries, may be exempt. Further, when legislation is introduced there may be limited resources devoted to their policing. The introduction of shift or relay systems complicates the job of policing factory legislation. Therefore it is not just the legislation enacted over working hours but also the resources devoted to enforcing this legislation that is important in determining the outcome of the class struggle in relation to working hours.

In contrast to individual-level explanations, Commons (1921) considered the role of classes and respective class power in the reduction of working hours. We can observe the importance of particular disputes in the conflict over working hours. Moreover 
Commons suggested that employers may see their class interest as overriding their individual self-interest:

In the Massachusetts hearings even the paper manufacturers who have already adopted the eight-hour day in competition with others on the twelve-hour day nevertheless, with one exception, opposed state legislation requiring their competitors to adopt it. Their objection is incomprehensible from the standpoint of self-interest. It can only be explained from the standpoint of class interest. They oppose a law which would benefit themselves individually because they stand by other employers who would not be benefited by it. If this class interest of employers is so great as to outweigh self-interest, surely such employers cannot raise the objection to this law that it is class legislation. If they suppress their private opinions in the interest of their class opinions, they have already disqualified themselves from objecting to legislation that treats them as a class. (1921, 817-818)

Thus we have a clear distinction, from Commons, between individual and class interest and the observation that in working hour legislation, class interest may well outweigh individual interest. ${ }^{7}$ Conflict over working hours should thus best be considered a struggle between respective classes (as in Commons and Marx), perhaps mediated through trade unions and so on rather than in terms of individual optimization, characteristic of the neoclassical approach. It thus appears that there exists considerable methodological overlap in the account of working hour determination offered by Commons and Marx.

Thorstein Veblen considered institutions to be a set of norms or ideals that are imperfectly reproduced or internalized through habit in successive generations of individuals $(1919,242-243$; Dugger 1979, 902). Accepting this we suggest that in the context of working hours, there emerge normal and accepted hours of work. These institutions are a stimulus and guide to behavior; therefore the preferences of an individual are not fundamental causal factors: "Since, in the institutionalist view, the range of alternatives open to men is determined by the institutional structure or context into which they are born, the place to start is with that institutional structure" (Dugger 1979, 902). The law itself is part of the structure within which people work, and the works of Marx, Commons, and Copeland all emphasize the conflict over legal restrictions on working hours.

In Marx's analysis normal hours are historically and socially contingent and tend to depend upon the work practice in a given industry or manufacturing process, societal norms, and formal legislation enacted to set limits on working hours. The theory of class struggle in Marxian economics implies a different explanatory level from the analysis offered by neoclassical economists. Marx suggested "the establishment of a norm for the working day, presents itself as a struggle between collective capital, i.e. the class of capitalists, and collective labour, i.e. the working class" $(1976,344)$. The detailed specification of working hours, including breaks, developed gradually, and "[t]heir formulation, 
official recognition and proclamation by the state were the result of a long class struggle" (394-395). Marx was also critical of individualist accounts of working hour determination: "The history of the regulation of the working day in certain branches of production, and the struggle still going on in others over this regulation, prove conclusively that the isolated worker, the worker as a 'free' seller of his labour-power, succumbs without resistance once capitalist production has reached a certain stage of maturity" (412). Therefore it is contended here that understanding the dynamics of working hours in terms of respective class power, rather than as an outcome of individual choice, generates more convincing explanations of movements through time. ${ }^{8}$

A number of factors constrain the maximum working day. First, there is a physical limit to the hours of work: "Within the 24 hours of the natural day a man can only expend a certain quantity of his vital force" (Marx 1976, 341). Second, there is a moral constraint which limits the hours people work: "The worker needs time in which to satisfy his intellectual and social requirements, and the extent and the number of these requirements is conditioned by the general level of civilisation" (341).In addition to these factors, the normal hours of work fluctuate through time as a consequence of the class struggle. Marx suggested, "The working day is, therefore, determinable, but is, per se, indeterminate" $(1954,223) .{ }^{9}$ We interpret this passage as meaning the following. At a particular moment, for a particular society, we can observe, empirically, what the normal and accepted hours of work are. But, in attempting to theorize or model working hours we cannot uniquely determine what they will be in the same way, say, as some models of value and price give determinate relative prices. ${ }^{10}$ Theoretically and formally there is indeterminacy over the normal and accepted hours of work, and this indeterminacy is more akin to a problem such as bilateral monopoly, with the capitalist and working classes as the "atoms of the system" rather than that of a unique individualist equilibrium model proposed in the neoclassical labor-leisure choice framework. There is also a lower limit to the length of the working day, the minimum necessary for capitalism to be viable.

In the conflict over working hours between classes there emerge industries of particular strategic importance. Marx suggested, "Capital's drive towards a boundless and ruthless extension of the working day is satisfied first in those industries which were first to be revolutionized by water-power, steam and machinery" $(1976,411)$. These industries included cotton, wool, flax, and silk. However, while this had initially been the primary point for conflict, the new work regime had begun to be adopted in other industries. Through the Victorian period, therefore, factory legislation began to be less exceptional and more general in nature. This view can be considered alongside M. A. Bienefeld's (1972) study of British industry, where it is suggested that the extension of working hours in the cotton textile industry prior to 1820 was pivotal in that it created pressures that would have led to an extension in other industries. Commons also identified industries which may serve as focal points in the conflict over working hours, in particular in continuous industries. He asserted, "Another reason why manufacturers oppose this legislation is their dread that the introduction of the eight-hour system by 
law in the continuous processes will be an entering wedge for introducing it in other processes and industries" (1921, 817). Variations in working hours in different industries, and industries where particular conflicts emerge, can therefore be insightfully interpreted in this light. ${ }^{11}$

A final relationship of significance in considering the determination of working hours concerns that between working hours and aggregate demand (as alluded to by Keynes above). Marx cited critically an 1879 article by Victor Drummond, which suggested, "The working-people have not kept up in culture with the growth of invention, and they have had things showered on them which they do not know how to use and thus make no market for. . . The problem remains, how to raise him as a consumer by rational and healthful processes, not an easy one, as his ambition does not go beyond a diminution of his hours of labour, the demagogues rather inciting him to this than to raising his condition by the improvement of his mental and moral powers" (Drummond cited in Marx 1978, 591). This raises the issue of aggregate demand. During the period in which Marx wrote output grew markedly, and the number and variety of commodities which workers consumed rose (although there is a debate over standards of living in the first phase of England's industrial revolution). During the twentieth century the trend in output was positive in almost all capitalist economies. The importance of the working class as a market for commodities is fundamental for the viability of capitalist growth. As noted in Philp 2001, if there is productivity growth, the benefits of which partially go to the working class, it is in the interests of capital to see these benefits passed on in the form of higher wages rather than reductions in working hours. This is because higher wages would entail increased consumption whereas the net effect of shorter hours on aggregate demand would be negative. The issue is related to the question of preferences. Of course neoclassical economics adopts an approach to rational choice in which preferences are unquestioned, but here Drummond was speculating on how the preferences of workers might be manipulated to stimulate a growth in consumer culture. ${ }^{12}$ It should be noted that rational-choice approaches which presume given preferences, such as that adopted in the labor-leisure choice framework, are incapable of investigating such processes since the power to manipulate preferences is, by assumption, denied.

\section{Reconciling Marxist and Institutionalist Approaches to Working Hours}

A number of similarities have emerged thus far. (1) Both Marxist and institutionalist approaches place emphasis on legal restrictions on working hours and how they are enforced. Authors in both traditions believe legal restrictions on working hours are, in part, necessary to prevent adverse health effects associated with long hours and that the outcome over these restrictions is a manifestation of the political power of respective classes. (2) Commons and Marx both distinguished between class and individual interest. They also both suggested that class interest may override individual 
interest when the two conflict. (3) There emerge social and historical norms over what are the normal and accepted hours of work, and these norms do not emerge out of the machinations of atomistic individual agents. (4) In the conflict over working hours there emerge particular industries which serve as focal, strategic points for conflict. Commons suggested "continuous" industries were one such battleground, and Marx identified the conflict in the cotton industry during Britain's industrial revolution as being particularly important. (5) The relationship between working hours and aggregate demand may also be important, particularly in the face of technological change and economic growth.

In spite of these similarities there may emerge incongruities between Marxist and institutionalist economists over aspects of the conflict over working hours, and these warrant some attention. Marx's treatment of the determination of working hours is located more broadly in his account of absolute surplus-value in the first volume of Capital. This is connected to his account of capitalist exploitation. The starting point of Marx's theory of surplus-value involves the recognition that where labor's consumption (including the labor required to repair and replenish the capital stock) only takes part of the day to produce, that worker can work effectively during the whole of a normal working day. If the duration of the latter is greater than that of the former then workers are being exploited. The time required to produce the daily means of subsistence is called necessary labor time, and the existence of surplus labor time presupposes that the length of the working day exceeds this time. ${ }^{13}$ Surplus labor time is defined as the additional time the worker works during a given day beyond that time required to produce his or her own means of socially determined subsistence and production. The rate of exploitation, or surplus-value, can therefore be given by the ratio of surplus to necessary labor time. ${ }^{14}$ Capital(ists) can adopt one of two general strategies to increase the rate of surplus-value. First, relative surplus-value production involves reducing the period of necessary labor time for a working day of given duration. This can be achieved through making workers work more intensively or through changing production methods (e.g., increasing the division of labor or introducing machinery). This implies reducing the length of time required to produce the goods of a value equivalent to those consumed by the workers. Second, absolute surplus-value involves increasing the rate of surplus-value through increasing the length of the working day. If necessary-labor time is of a fixed duration, increasing the length of the working day increases the period of surplus labor time. As the length of the working day increases, ceteris paribus, so the rate of exploitation increases up to the maximum working day. If we assume technology and the wage to be given, the problem of determining the rate of surplus-value is thus reduced to that of determining the length of the working day, and this duration is the outcome of class struggle and the consequent degree of development of capitalism. Many institutionalists may not concur with this Marxist description of capitalist exploitation, though it should be noted that this is a normative rather than explanatory point of difference. Hence the 
common ground concerning explaining what working hours are is not challenged by this particular objection.

A second objection might be made that Marx's account of conflict over the length of the working day relies on a labor theory of value. It should, however, be noted that Marx's account of the labor process is not rendered invalid, even if we accept the usual criticisms of his value analysis. Although Ian Steedman (1977) maintained that value magnitudes play no role in determining the rate of profit, he has suggested that the labor/labor-power distinction and the concept surplus labor are left untouched by the Sraffa-based critique of Marxian value theory. Further, "Marx's emphases on the labour process, on coercion therein, and on the ever-changing nature of the labour process resulting from both workplace conflicts and the competitive struggle" are not invalidated by the Sraffian critique (206). Steedman further recognized that chapter 10 of Capital's first volume contains "an excellent discussion of some of the many economic and political determinants of the length of the working day" $(77, n$. 1). The determinants of working hours alluded to in the previous section, thus, do not rely on a labor theory of value; hence our approach is not invalidated if institutionalists reject Marx's value reasoning.

\section{Conclusion}

This paper has considered a number of different approaches that can be adopted in answering the question of what determines working hours. It has been suggested that this question can be investigated on a number of different levels and that it is evident that the neoclassical rational-choice approach to working hour determination is inferior to the approach adopted by institutionalist and Marxist economists. Even limited claims about the validity of neoclassical analyses of working hours can be subject to doubt when we consider the empirical evidence advanced both within and on the periphery of mainstream economics. This has cast serious doubts over rational-choice accounts of decision making and the standard axioms of choice theory in particular.

An alternative approach to working-hour determination is offered by Marxian and institutional economics. The evolution of economies and economic development, coupled with the ongoing process of class conflict, presents a more satisfactory account of the causes of movements in working hours through time. In common with aspects of institutionalism, the development of norms emerging from the economic structure, rather than the machinations of atomistic individuals, offers an alternative causal process that can be used to examine change. This paper has argued that class power and the level of economic development are the main determinants of working hours. Finally we would like to note that this recognition need not entail that the results obtained by applied labor economists, researching in mainstream departments, have no empirical value. However, we contend that Marxist and institutionalist interpretations of empirical evidence may be more convincing than the neoclassical interpretations often offered 
in explanation. ${ }^{15}$ Labor economists would therefore do well to consider alternative theoretical frameworks and models and compare these explanations of empirical evidence with those offered using neoclassical theory. This paper contends that Marxian and institutional economics presents valid and insightful alternatives to such mainstream theory and that there is considerable common ground in their approaches to the question, what determines working hours?

\section{Notes}

1. Important contributions include Shapiro and Stiglitz 1984, Stiglitz 1987, Bowles 1985, and Bowles and Gintis 1990, 1994. For criticisms of this work see Spencer 2000, 2002.

2. John R. Commons considered not only the dynamics of international competitiveness but also the ethics of such arguments. He suggested, "II]f foreign markets cannot be captured unless laborers are forced to work twelve hours in continuous industries, then they are not worth capturing" $(1921,816)$.

3. The microfoundations approach to Marxism has been criticized from the perspective of orthodox Marxism (see Lebowitz 1988, 1994). In addition, Bruce Philp and David Young (2002) have criticized the microfoundations approach to Marxism from the perspective of the philosophy of science and from criticisms advanced within mainstream economic theory. These arguments can be applied equally to a rational-choice, microfoundations approach to working-hour determination.

4. The problems with rational-choice theory in the context of analytical Marxism are discussed, and elaborated upon, in Philp and Young 2002.

5. There may be practical difficulties for a given labor supply function also. Neoclassical economists have identified a number of problems that warrant attention For example, the backward-bending labor supply schedule may give rise to problems of stability. If there are parts of a labor supply function which also forward bend this may give rise to multiple equilibriums and a combination of unstable and locally stable equilibriums. For a discussion of these problems in the context of labor supply see Prasch 2000 and 2001 and Spencer 2001.

6. In recent years the "new" institutional economics has reinterpreted elements of institutionalism, partly using the methodology of neoclassical theory. This marks a distinct break from the old institutionalism of Thorstein Veblen, Commons, and Wesley Mitchell. The contradiction has been noted by Geoffrey Hodgson: "The irony, of course, is that the original institutionalism of Veblen and others emerged largely out of a critique of orthodox assumptions" (1988, 249-250). In the context of institutional economics, Hodgson (1988) has noted that the notion of an abstract individual implies a form of reductionism, which is also related to the doctrine of methodological individualism. Therefore, just as an assessment of the merits of rational choice methodology is relevant in the debate between orthodox and analytical Marxism, so this parallels the debate concerning the application of rational choice methods by the new institutionalists. To illustrate this, it is useful to note Douglass North's (1986) endorsement of the methodology of analytical Marxism.

7. In their comparison of Marxism and institutionalism, William Dugger and Howard Sherman have suggested, "A weakness of institutionalism is that sometimes institutionalists ignore class altogether. For example, the struggle over the eight-hour day is seen as a succession of unions versus a succession of captains of industry struggling over the working rules of their particular industries" $(1994,106)$. Commons, however, recognized the explanatory importance of class conflict in his consideration of working hours in continuous industries.

8. This is not to suggest that an individual worker's preferences play no role in the determination of his or her working hours. For example, an individual may freely choose to take a 
part-time, as opposed to full-time, job or to work or not work overtime, or to take a second job. However, our position is that the circumstances under which such a worker makes these decisions-normal working hours and wage rates-are collectively determined.

9. The Penguin edition of Capital I (Marx 1976) translates this sentence thus: "The working day is therefore capable of being determined, but in and for itself indeterminate [sic]" (341).

10. The question of whether Karl Marx's value theory is a theory of (relative) prices is, of course, controversial.

11. Edwin West (1983) has suggested that variation in working hours between workers and industries undermines Marx's theory. (For a discussion of West's analysis, see Minkler 1986.). In the context of joint production, if we define the rate of surplus-value in aggregate terms such problems are circumvented (Morishima 1973). Defining the rate of surplus-value in aggregate also circumvents problems stemming from variations in working hours between industries/ sectors.

12. This may be possible if the capitalist class are able to foster the myth or misconception that long working hours are in the interest of the working class. Such enabling myths could be the result of power relationships which enable one class to dominate another.

13. Surplus labor time is not unique to capitalism. Where capitalism differs from previous modes of production is in the manifestation of surplus labor time as surplus-value (i.e., the sum of profit, interest, and rent). Marx noted, "It is just as important for a correct understanding of surplus-value to conceive it as merely a congealed quantity of surplus labour-time, as nothing but objectified surplus labor, as it is for a proper comprehension of value in general to conceive it as merely a congealed quantity of so many hours of labor, as nothing but objectified labor. What distinguishes the various economic formations of society-is the form in which this surplus labor is in each case extorted from the immediate producer, the worker" (1976, 325).

14. In Capital there are three definitions of the rate of surplus-value $(1976,671)$-the ratio of surplus-value to the value of labor power, the ratio of unpaid to paid labor, and the ratio of surplus to necessary labor time. Michio Morishima demonstrated the formal equivalence of these ratios $(1973,46-51)$. One should also note that "unpaid labor" does not, in Marx's analysis, refer to labor performed in the nonmarket, household sphere of the economy. However, framing questions of distribution in the market, in other words, capitalist sphere of the economy, in terms of time does give a plausible route to integrating theories of capitalist exploitation, with those concerning labor that is unpaid in the household sector (see Laibman 1992, 55-70).

15. For example, M. A. Bienefeld (1972) sought to interpret the movement and development of working hours in a neoclassical framework. But Bienefeld's excellent historical account is not well explained by such models, and this historical evidence is better interpreted in terms of absolute surplus-value production, class conflict, and processes of economic development (i.e., using Marxian theories). Further, mainstream labor economists have produced clear empirical evidence showing discrimination on the basis of ethnicity, language, sexuality, and gender. While the underlying neoclassical rational-choice frameworks frequently assumed are problematic for reasons outlined in this paper, such empirical work has value when reinterpreted using Marxian and institutionalist theory.

\section{References}

Bienefeld, M. A. Working Hours in British Industry: An Economic History. London: London School of Economics and Political Science, 1972.

Bosch, Gerhard, and Steffen Lehndorff. "Working-Time Reduction and Employment: Experiences in Europe and Economic Policy Recommendations." Cambridge Journal of Economics 25 (March 2001): 209-343. 
Bowles, Samuel. "The Production Process in a Competitive Economy: Walrasian, Neo-Hobbesian, and Marxian Models.” American Economic Review 75 (March 1985): 16-36.

Bowles, Samuel, and Herbert Gintis. "Contested Exchange: New Microfoundations for the Political Economy of Capitalism." Politics and Society 18 (June 1990): 165-222.

"Credit Market Imperfections and the Incidence of Worker-Owned Firms." Metroeconomica 45 (October 1994): 209-223.

Buell, P., and L. Breslow. "Mortality from Coronary Heart Disease in California Men Who Work Long Hours.” Journal of Chronic Diseases 11 (1960): 615-626.

Cameron, John, and Tidings Ndhlovu. "Keynes and the Distribution of Uncertainty: Lessons from the Lancashire Cotton Spinning Industry and the General Theory.” Review of Social Economy 57 (March 1999): 99-123.

Commons, John. "Eight-Hour Shifts by Federal Legislation." In John Commons, editor, Trade Unionism and Labor Problems, Second Series. Boston: Athenaeum Press, 1921, 807-823.

Copeland, Morris. "Economic Theory and the Natural Science Point of View." American Economic Review 21 (March 1931): 67-79.

Davidson, Paul. Controversies in Post Keynesian Economics. Aldershot, U.K.: Edward Elgar, 1991.

Dugger, William. "Methodological Differences between Institutional and Neoclassical Economics." Journal of Economic Issues 13, no. 4 (December 1979): 899-909.

Dugger, William, and Sherman, Howard. "Comparison of Marxism and Institutionalism.” Journal of Economic Issues 28 (March 1994): 101-127.

Garfinkel, Alan. "Reductionism." In The Philosophy of Science, edited by Richard Boyd, Philip Gasper, and J. D. Trout. London: MIT Press, 1991, 443-459.

Green, Francis. "It's Been a Hard Day's Night: The Concentration and Intensification of Work in Late 20th Century Britain.” British Journal of Industrial Relations 39, no. 1 (March 2001): 53-80.

Grether, D. W., and C. R. Plott. "Economic Theory of Choice and the Preference Reversal Phenonomenon." American Economic Review 69, no. 4 (December 1979): 623-638.

Hobsbawm, Eric. Labouring Men. London: Weidenfeld and Nicolson, 1968.

Hodgson, Geoffrey. "Institutional Economic Theory: The Old Versus the New." Review of Political Economy 1, no. 3 (July 1988): 249-269.

-. Economics and Utopia. London: Routledge, 1999.

Howard, Michael C., and John E. King. A History of Marxian Economics, Vol. II. London: MacMillan, 1991.

Keynes, John Maynard. The Collected Writings of John Maynard Keynes, Vol. 27, Activities 1940-1946: Employment and Commodities: Shaping the Post-War, edited by Donald Moggridge. London: MacMillan, 1980.

—. The Collected Writings of John Maynard Keynes, Vol. 19, Activities, 1922-1929: The Return to Gold and Industrial Policy, edited by Donald Moggridge. London: Macmillan, 1981.

Laibman, David. Value, Technical Change, and Crisis. New York: M. E. Sharpe, 1992.

Lebowitz, Michael. “Is 'Analytical Marxism’ Marxism?” Science and Society 52, no. 2 (Summer 1988): 191-214. . "Analytical Marxism and the Marxian Theory of Crisis." Cambridge Journal of Economics 18, no. 2 (March 1994): 163-179.

Leowenstein, George, and Daniel Adler. “A Bias in the Prediction of Tastes.” Economic Journal 105 (July 1995): $163-179$.

Loomes, Graham, and Robert Sugden. "Regret Theory: An Alternative Theory of Rational Choice under Uncertainty.” Economic Journal 92 (December 1982): 805-824.

Marx, Karl. Capital. Vol. 1. London: Lawrence and Wishart, 1954.

—. Capital. Vol. 1. London: Penguin Books, 1976.

_. Capital. Vol. 2. London: Penguin Books, 1978.

Miller, Edythe. "Institutional Economics: Philosophy, Methodology and Theory." Social Science Journal 15 (January 1978): 13-25.

Minkler, Lanse. "In Defense of Marx on the Length of the Working Day." Economic Forum XVI (Summer 1986-7): 105-110. 
Modigliani, Franco, J.P. Fitoussi, B. Moro, D. Snower, R. Solow, A. Steinherr, and P. Sylos Labini. "An Economists' Manifesto on Unemployment in the European Union." Banco Nazionale Del Lavoro Quarterly Review 206 (September 1998): 327-361.

Morishima, Michio. Marx's Economics. Cambridge: Cambridge University Press, 1973.

North, Douglass C. "Is It Worth Making Sense of Marx?" Enquiry 29 (1986): 57-63.

Philp, Bruce. "Marxism, Neoclassical Economics, and the Length of the Working Day." Review of Political Economy 13, no. 1 (January 2001): 27-39.

Philp, Bruce, and David Young. "Preferences, Reductionism, and the Microfoundations of Analytical Marxism." Cambridge Journal of Economics 26, no. 3 (May 2002): 313-329.

Prasch, Robert E. "Reassessing the Labor Supply Curve." Journal of Economic Issues 34, no. 3 (September 2000): 679-692.

"Work, Leisure and the Labor Supply Curve: A Reply." Journal of Economic Issues 35, no.4 (December 2001): 1001-1007.

Schor, Juliet. The Overworked American: The Unexpected Decline of Leisure. New York: Harpercollins, 1991.

Shapiro, Carl, and Joseph Stiglitz. "Equilibrium Unemployment as a Worker Discipline Device." American Economic Review 74 (June 1984): 433-444.

Sparks, K., C. Cooper, Y. Fried, and A. Shirom. "The Effects of Hours of Work on Health: A Meta-Analytic Review." Journal of Occupational and Organizational Psychology 70, no. 4 (December 1997): 391-408.

Spencer, David. "The Demise of Radical Political Economics? An Essay on the Evolution of Capitalist Production." Cambridge Journal of Economics 24 (September 2000): 543-564.

"All Work and No Play? A Comment on Prasch's 'Reassessing the Labor Supply Curve." Journal of Economic Issues 35, no. 4 (December 2001): 995-1000.

_. "Shirking the Issue? Efficiency Wages, Work Discipline, and Full Employment." Review of Political Economy 14, no. 3 (July 2002): 313-327.

Steedman, Ian. Marx after Sraffa. London: Verso, 1977.

Stiglitz, Joseph. "The Causes and Consequences of the Dependency of Quality on Price." Journal of Economic Literature 25 (March 1987): 1-49.

Tversky, Amos, Paul Slovic, and Daniel Kahneman. "The Causes of Preference Reversal." American Economic Review 80, no. 1 (March 1990): 204-217.

Veblen, Thorstein. The Place of Science in Modern Civilisation and Other Essays. New York: Hübsch, 1919.

West, Edwin. "Marx's Hypotheses on the Length of the Working Day." Journal of Political Economy 91, no. 2 (April 1983): 266-281. 